Bulletin of the Natural History Museum, 2020, 13: 51-58.

Received 3 Aug 2020; Accepted 11 Sep 2020.

doi: $10.5937 / \mathrm{bnhmb} 2013051 \mathrm{~A}$

UDC: $551.7(497.113) "$ "628.42"

UDC: $551.7(497.113) "$ "628.42"

Original scientific paper

\title{
NEW DATA ON THE STRATIGRAPHY OF BADENIAN FROM KRČEDIN AREA (NORTHERN SERBIA, CENTRAL PARATETHYS)
}

\author{
FILIP ANĐELKOVIĆ ${ }^{1 *}$, NATALIJA BATOĆANIN ${ }^{2}$
}

${ }^{1}$ University of Belgrade, Faculty of Mining and Geology, Department of Regional Geology, Kamenička 6, 11000 Belgrade, e-mail: filip.andjelkovic1993@gmail.com

${ }^{2}$ University of Belgrade, Faculty of Geography, Department of Geography, Studentski trg 3,11000 Belgrade

Badenian sediments are found for the first time in the surroundings of the Krčedin village. They represent remnants of the Central Paratethys marginal sea. The sediments are represented by a basal conglomerate unit overlain by pure and sandy marl. Foraminifera and rare ostracods are present, limited to the marls. Normal gradation and the prevalence of planktonic foraminifera suggest a rapidly deepening basin.

Key words: Krčedin, Badenian, Central Paratethys, foraminifera

\section{INTRODUCTION}

Badenian sediments play a key role in defining what the Central Paratethys actually was, at least in the Serbian part. The only true marine depositional environment in the Neogene of Serbia belongs to the Badenian 
Stage. These sediments are of varying lithostratigraphic affinities, sedimentological characteristics, palaeontological content and palaeogeographic significance. Despite all of these differing attributes, they generally fit well into a scheme of a synrift formation, or more precisely, as a rift climax system tract (as defined by Prosser 1993 and elaborated on in: Matenco \& Radivojević 2012, ter Borgh 2013, Balazs et al. 2017 and Holz et al. 2017). That means they are witnesses of the initial rifting and basin formation, later being exhumed during the Plio-Pleistocene basin inversion (Anđelković 2020).

\section{GEOLOGICAL SETTING}

The locality is situated on the easternmost slopes of Fruška Gora Mt., occupying the Koševac ridge (Figure 1). Badenian sediments have not been previously known from the Krčedin area, so this paper presents their first description. They have been confirmed from an outcrop in a road cut leading to the Krčedin quarry. They may also be present in a high cliff slightly to the east of the quarry. The coordinates of the roadcut outcrop are $45^{\circ} 10^{\prime} 5^{\prime \prime} \mathrm{N} 20^{\circ} 8^{\prime} 15^{\prime \prime} \mathrm{E}$.

Underlying the Badenian are Lower Cretaceous turbidites most probably belonging to the Vardar Zone (Dimitrijević \& Dimitrijević 2009, Toljić et al. 2018, Toljić et al. 2019, Anđelković 2020). The overlying strata are composed of the Pleistocene proluvial sediments and loess (Anđelković 2020), with the possible presence of the Sarmatian (Čičulić-Trifunović 1994).

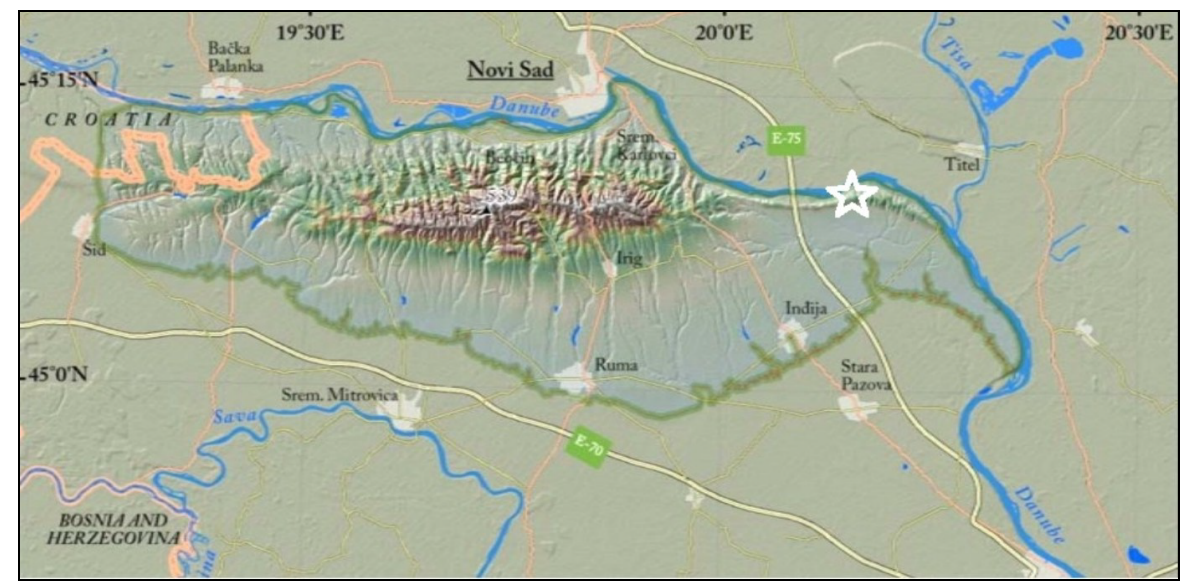

Fig. 1. - Geographical position of the Fruška Gora mt. in Northern Serbia and its surrounding area. The white star marks the Krčedin locality. (Meszaros 2013 - modified). 


\section{MATERIAL AND METHODS}

The material is represented by hand specimens and sediment samples. The outcrop had been cleared of Holocene deposits and cleaned before sampling. Three representative samples have been taken: one from the conglomeratic basal unit and two from overlying sandy marls and marls. They have been packed in appropriate bags and marked. Karrimor compass and GPS smartphone app have been used for orienting the outcrop.

Samples have been later analyzed in laboratory. The conglomerates were broken apart and the constituent pebbles petrographically determined. Marl samples were studied in two different methods: part of them have been disintegrated and sieved for micropalaeontological research, and the other part cut and polished into thin sections.

Thin sections were investigated under the Leica DMLSP petrographic microscope. Micropalaeontolgical samples were investigated under the Bio Optica microscope.

\section{RESULTS}

The results can be divided into following fields: sedimentological description of the rocks found and a biostratigraphic research.

\section{Sedimentology and lithostratigraphy}

Four lithofacies have been observed: A - conglomeratic basal unit, B microconglomerate, $\mathrm{C}$ - sandy marl, and D - marl (Figures 2 and 3). Lithofacies have been determined according to their sedimentological characteristics. The conglomerates have been examined in hand and contain fragments of underlying Lower Cretaceous sediments. The microconglomerate stratum is relatively thin (about $20 \mathrm{~cm}$ ) and represents the transition from conglomerates to sandy marl.

Sandy marl of lithofacies $\mathrm{C}$ is composed of micrite and clay minerals, forming an aphanatic framework, with sand and chert grains. The lithofacies D (pure marl) is very similar to the previous one, with the difference in the amount of siliciclastic material.

\section{Micropalaeontology and biostratigraphy}

Lithofacies A and B are palaeontologically sterile. The microfaunal content of the lithofacies C and D is further described. Microfossils are represented by foraminifera, some macrofaunal fragments and rare ostracods. They have been studied in thin section and in residue after sieving.

Foraminifera are mostly of planktonic type, with some benthic specimens. Planktonic foraminifera include Orbulina suturalis, Praeorbu- 


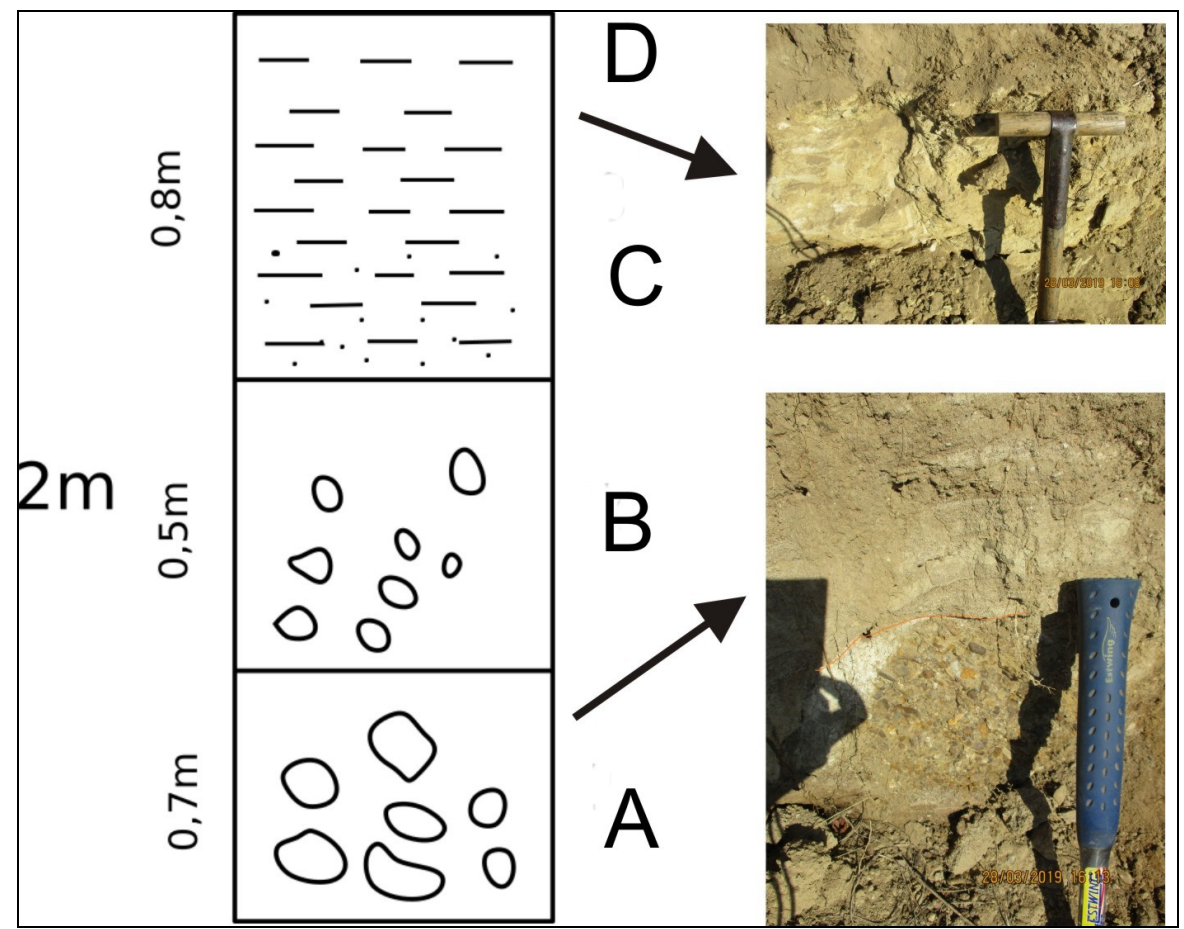

Fig. 2. - Lithostratigraphic log showing the stratigraphical position and lithofacies of Badenian sediments in the studied locality. Explanation: A basal conglomerate, $\mathrm{B}$ - microconglomerate, $\mathrm{C}$ - sandy marl, D - pure marl.

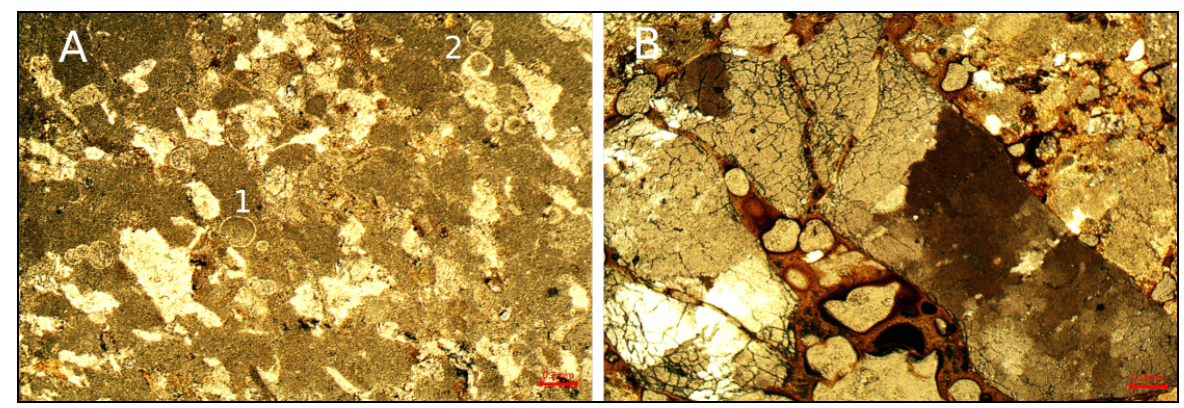

Fig. 3. - Microphotographs of the studied thin sections. A: lithofacies $\mathrm{C}$ sandy marl with less visible foraminifera, containing a chert grain. B: lithofacies D marl with abundant foraminifera: Globigerina sp., (2) Globigerinoides sp., Orbulina suturalis (1).

lina sp., Globigerina sp. and Globigerinoides sp. Benthic foraminifera are represented by scarce Borelis melo and Elphidium sp. Presence of only one ostracod species, Leguminocythereis martonfii, is confirmed. Fragments of 
macrofauna have been recorded, but without stratigraphic significance (Figures 3 and 4).

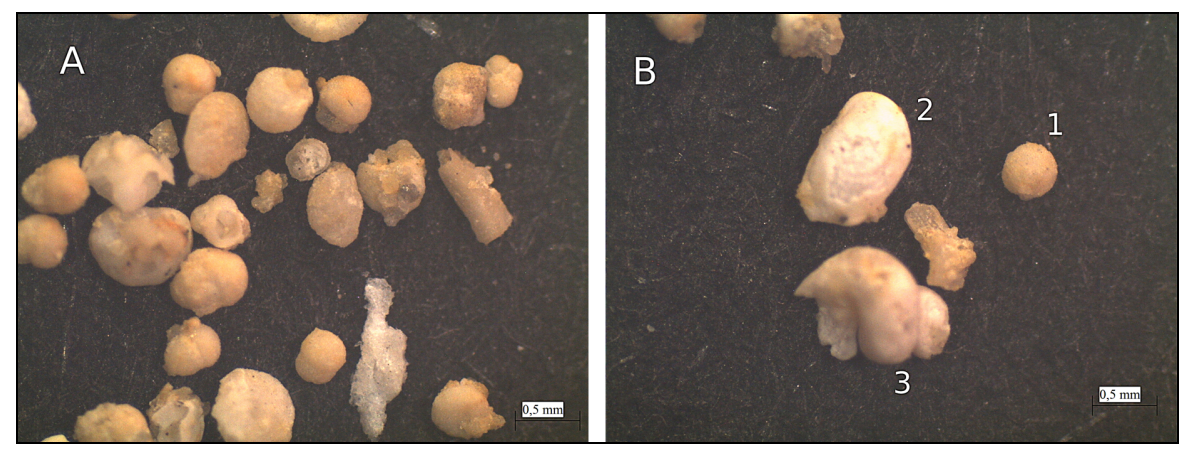

Fig. 4. - Microphotographs of the sieved micropalaeontogical samples. A: Middle Badenian Upper Lagenid zone planktonic foraminifera, B: foraminifer (Orbulina suturalis) (1), ostracod (Leguminocythereis martonfii) (2), gastropod fragment (3).

\section{DISCUSSION}

What can be inferred from the previous two chapters is that the combination of sedimentology and biostratigraphy gives the palaeogeographical meaning to the collected data. The lithofacies clearly show a normal gradational sequence, beginning with conglomerates, then proceeding with microconglomerates and ends with sandy marls and marls. This sequence indicates that the conglomerates form a basal unit, as a result of transgression, and the marls are products of a deepening environment, deposited in calmer waters. This is confirmed by micropalaeontology, because of the domination of planktonic foraminifera and almost-absent ostracoda.

Biostratigraphy-based chronostratigraphy has been established according to the timeline given in Kovačova et al. (2009) (Figure 5). The presence of Orbulina suturalis indicates the Upper Lagenid Zone, which is in turn placed in the Middle Badenian.

Such features of the Badenian sediments show that their formation is tied to the initial marine flooding in the Miocene, recorded in various parts of the Pannonian basin's southern rim (Rundić et al. 2013, Rundić \& Knežević 2017, Pavelić \& Kovačić 2018, Anđelković \& Radivojević 2019, Mandić et al. 2019, Rundić et al. 2019). The event may or may not be synchronous in all the parts. This flooding happened during the time when the basin was in the rift climax system tract (see Introduction). However, 
the subsidence rate was quite high, with conglomerates proceeding directly into marls, without the subreefal limestone usually found in the area.

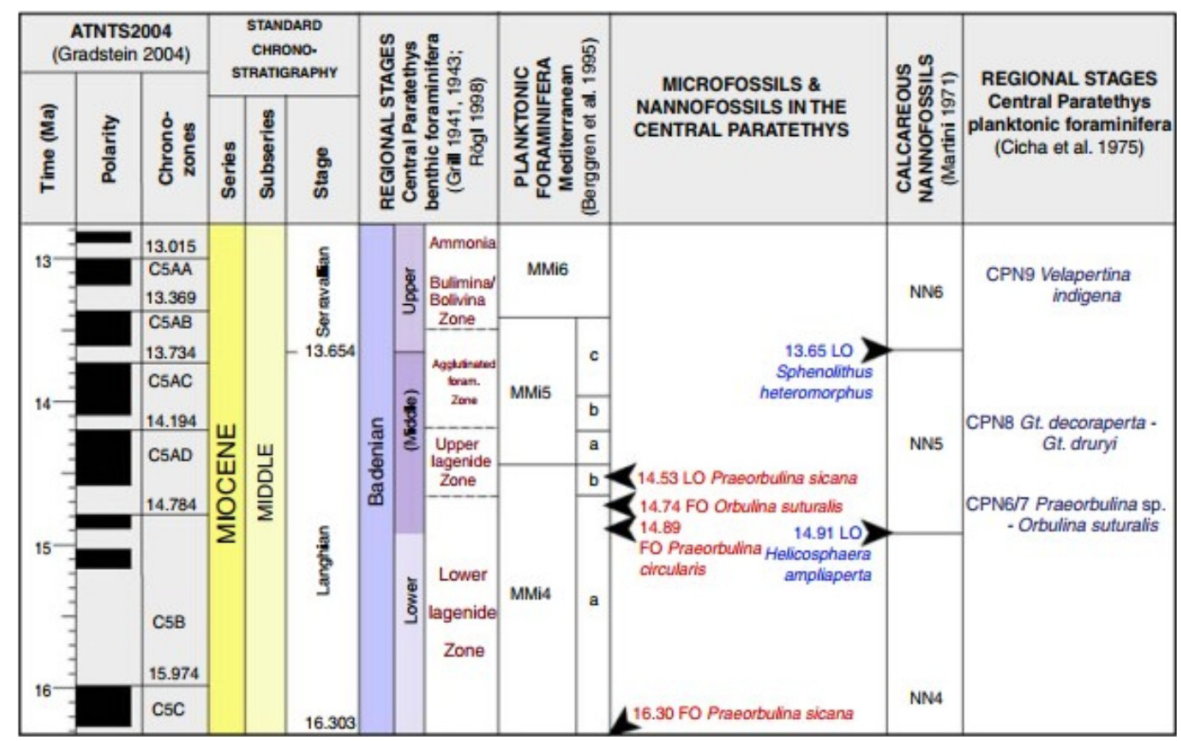

Fig. 5. - Stratigraphic chart and biozonal correlation of Badenian in the Central Paratethys (Kováčová et al. 2009).

\section{CONCLUSIONS}

By taking into account all the evidence presented here, one can conclude that the knowledge of these sediments is vital to the understanding of the Badenian marine transgression in a wider area (the southern rim of the Pannonian basin). Furthermore, the sediments which were determined as Badenian in age are first of their kind in this locality. As the Sarmatian was known for a long time (Čičulić-Trifunović 1994), the knowledge of the Middle Miocene is now complete.

What can be inferred from this is that this is only the "first find" and that further research is definitely welcome. We would advise on extensive and high-resolution stratigraphical mapping of the area, as we are convinced that the Badenian sediments can be found elsewhere in this locality. In addition, some up-to-date analytical techniques can be used. We recommend using sedimentary geochemistry, especially the stable isotope studies.

\section{REFERENCES}

Anđelković, F., Radivojević, D. (2019): Evidence for Badenian marine transgression in Belgrade (Serbia). In: AAPG Europe Regional Conference Vienna book of abstracts: 162. - AAPG, Vienna. 
Anđelković, F. (2020): Pleistocene proluvial sediments in the vicinity of Fruška gora: an example from Krčedin quarry. - Reports of the Serbian Geological Society for the year 2019: 47-53.

Balász, A., Burov, E., Matenco, L., Vogt, K., Francois, T., Cloething, S. (2017): Symmetry during the syn- and post-rift evolution of extensional back-arc basins: the role of inherited orogenic structures. - Earth and Planetary Science Letters 462: 86-98.

Čičulić-Trifunović, M. (1994): Explanatory booklet for the Basic Geological Map of the Federal Republic of Yugoslavia, sheet Inđija: 1-67.

Dimitrijević, M. N., Dimitrijević, M. D. (2009): The Lower Cretaceous paraflysch of the Vardar Zone: composition and fabric. - Annales Geologiques de la Peninsule Balkanique 70: 9-21.

Holz, M., Bono Vilas-Boas, D., Brasileiro Troccoli, E., Carneiro Santana, V., Augusto-Vidigal Souza, P. (2017): Conceptual models for sequence stratigraphy of continental rift successions. In: Montenari, M. (ed.): Stratigraphy and Timescales 2: 119-186. - Elsevier.

Kováčová, P., Emmanuel, L., Hudáčková, N., Renard, M. (2009): Central Paratethys paleoenvironment during the Badenian (Middle Miocene): evidence from foraminifera and stable isotope (d13C and d18O) study in the Vienna Basin (Slovakia). - International Journal of Earth Sciences 98: 1109-1127.

Mandic, O., Rundić, Lj., Ćorić, S., Pezelj, Đ., Theobalt, T., Sant, K., Krijgsman, W. (2019): Age and mode of the Middle Miocene marine flooding of the Pannonian Basin: constraints from Central Serbia. - Palaios 342: 1-25.

Matenco, L., Radivojević, D. (2012): On the formation and evolution of the Pannonian Basin: constraints derived from the structure of the junction area between the Carpathians and Dinarides. - Tectonics 31: 1-31. TC6007, doi:10.1029/2012TC003206

Pavelić, D., Kovačić, M. (2018): Sedimentology and stratigraphy of the Neogene rift-type North Croatian Basin (Pannonian Basin System, Croatia): a review. Marine and Petroleum Geology 91: 455-469.

Prosser, S. (1993): Rift-related linked depositional systems and their seismic expression. In: Tectonic and seismic sequence stratigraphy 71: 117-144. Geological Society of London.

Rundić, Lj., Knežević, S., Rakijaš, M. (2013): Middle Miocene Badenian transgression: new evidence from the Vrdnik Coal Basin (Fruška Gora mt., northern Serbia). - Annales Geologiques de la Peninsule Balkanique 74: 9-23.

Rundić, Lj., Knežević, S. (2017): The Miocene fossiliferous sites of the Avala mt. (Belgrade area, Serbia) and their importance. - Bulletin of the Natural History Museum 10: 29-41.

Rundić, Lj., Ganić, M., Knežević, S., Radivojević, D., Radonjić, M. (2019): Stratigraphic implications of the Mio-Pliocene geodynamics in the area of $\mathrm{mt}$. Avala: new evidence from Torlak Hill and Beli Potok (Belgrade, Serbia). Geologia Croatica 72/2: 109-128. 
ter Borgh, M. (2013): Connections between sedimentary basins during continental collision: how tectonic, surface and sedimentary processes shaped the Paratethys. In: PhD Thesis: 1-204. - Utrecht University.

Toljić, M., Matenco, L., Stojadinović, U., Willingshofer, E., Ljubović-Obradović, D. (2018): Understanding fossil fore-arc basins: inference from the Cretaceous Adria-Europe convergence in the NE Dinarides. - Global and Planetary Change 171: 1-18.

Toljić, M., Stojadinović, U., Krstekanić, N. (2019): Vardar Zone: new insights into the tectono-depositional subdivision. In: II Congress of geologists of Bosnia and Herzegovina in Laktaši - proceedings: 62-73. - Udruženje geologa Bosne i Hercegovine, Ilidža.

\title{
НОВИ ПОДАЦИ О СТРАТИГРАФИЈИ БАДЕНА ОКОЛИНЕ КРЧЕДИНА (СЕВЕРНА СРБИЈА, ЦЕНТРАЛНИ ПАРАТЕТИС)
}

\author{
ФИЛИП АНЋЕЛКОВИЋ, НАТАЛИЈА БАТОЋАНИН
}

\section{Р Е 3 И М Е}

Седименти баденског ката представљају најрепрезентативније остатке Централног Паратетиса, будући да је само у то време постојала права маринска седиментација у целом Панонском басену. Баденски седименти околине Крчедина први пут су описани у овом раду. Представљени су базалном серијом конгломерата и микроконгломерата, као и лапорцима и песковитим лапорцима који леже преко базалне серије. У лапорцима су откривени фосили микрофауне који се састоје од бројних фораминифера и ретких остракода. Фораминифере су углавном планктонске и говоре у прилог постојања нешто дубље и мирније средине у којој су депоновани ови седименти. Све ове особине представљају одраз брзог отварања и продубљавања басена у оквиру системског појаса максимума рифтогенезе, које је на основу фораминифера у овом суббасену датирано као доњи или средњи баден. Аутори предлажу даља детаљнија истраживања овог подручја и уверени су да се баденски седименти могу пронаћи и на још неким изданцима. 